\title{
Mechanistic perspectives of calorie restriction on vascular homeostasis
}

\author{
LIU Yue, CHEN HouZao* \& LIU DePei* \\ State Key Laboratory of Medical Molecular Biology, Department of Biochemistry and Molecular Biology, Institute of Basic Medical Sciences, \\ Chinese Academy of Medical Sciences \& Peking Union Medical College, Beijing 100005, China
}

Received April 30, 2014; accepted July 4, 2014

\begin{abstract}
Calorie restriction $(\mathrm{CR})$ is a dietary regime based on low calorie intake. CR without malnutrition extends lifespan in a wide range of organisms from yeast to rodents, and CR can prevent and delay the onset of age-related functional decline and diseases in human and non-human primates. CR is a safe and effective intervention to reduce vascular risk factors in humans. In recent years, studies in rodents have provided mechanistic insights into the beneficial effects of CR on vascular homeostasis, including reduced oxidative stress, enhanced nitric oxide (NO) bioactivity, and decreased inflammation. A number of important molecules, including sirtuins, AMP-activated protein kinase, mammalian targets of rapamycin, endothelial nitric oxidase and their regulatory pathways are involved in the maintenance of vascular homeostasis. Evidence has shown that these pathways are responsible for many aspects of CR's effects, and that they may also mediate the effects of CR on vasculature.
\end{abstract}

calorie restriction (CR), vascular homeostasis, Sirtuin 1 (SIRT1), AMP-activated protein kinase (AMPK), mammalian target of rapamycin (mTOR), endothelial nitric oxide synthase (eNOS)

Citation: Liu Y, Chen HZ, Liu DP. Mechanistic perspectives of calorie restriction on vascular homeostasis. Sci China Life Sci, 2014, 57: 742-754, doi: $10.1007 / \mathrm{s} 11427-014-4709-\mathrm{Z}$

Calorie restriction (CR), sometimes referred to as dietary restriction (DR), is a dietary regime based on low calorie intake. CR is usually defined as decreasing the calorie intake about $20 \%-40 \%$ of the ad libitum (AL) diet without compromising the intake of essential nutrients [1]. Since McCay first reported that CR extended lifespan of rats almost eight decades ago [2], CR is now believed to be the only non-pharmacological intervention to extend lifespan. It has been proven that $\mathrm{CR}$ prolongs lifespan in diverse organisms, including yeast, worms, flies and rodents [3]. Long-term CR also significantly improves age-related and all-cause survival in rhesus monkeys implying it also prolongs lifespan in higher mammals [4,5]. Furthermore, studies in humans and monkeys also showed that a reduction in calorie intake without malnutrition prevents and delays the

*Corresponding author (email: houzao@gmail.com; liudp@pumc.edu.cn) onset of age-related functional decline and also of diseases such as type-2-diabetes, cancer and cardiovascular diseases (CVDs) [3,6].

Vascular homeostasis is a healthy and balanced state, in which endothelial cells (ECs), vascular smooth muscle cells (VSMCs), fibroblasts and other bone marrow-derived cells in the vascular wall coordinate with environmental cues to maintain an appropriate blood pressure and control a proper tissue blood perfusion. Vascular diseases result from a loss of vascular homeostasis. During the past decade, the leading two causes of death worldwide were ischemic heart disease and stroke [7], both of which are directly caused by aberrant vascular homeostasis.

CR exerts protective effects on vascular homeostasis. CR attenuates atherosclerosis and improves age, obesity and diabetes-related vascular dysfunction in rodents [8-11]. In rhesus monkeys, the incidence of CVDs was 50\% reduced 
by CR [4]. Studies also suggest beneficial effects of CR on vascular homeostasis in humans. Food restriction during the Second World War in Norway caused a sharp decline in mortality of CVDs, while the mortality began to increase rapidly after the war [12]. In addition, the Japanese Okinawan are naturally calorie restricted due to their traditional low energy-content diet. Their mortality from coronary artery diseases is much lower than that of other Japanese and Americans [13]. These two epidemiological studies of unintentionally induced $\mathrm{CR}$ provide evidences that $\mathrm{CR}$ may also reduce the mortality of CVDs in humans.

In this review, we introduce the beneficial effects of CR on vascular homeostasis in rodents and primates including humans, and then discuss the possible molecular pathways that mediate its effects on vasculature, which hold a great promise as therapeutic targets in treating vascular diseases.

\section{CR preserves vascular homeostasis}

\subsection{CR reduces risk factors of vascular diseases}

The risk factors for CVDs include central obesity, high blood pressure, elevated fasting plasma glucose level, dyslipidemia, and a high level of inflammation. Reducing calorie intake is a very effective and reliable way to reduce the risk for CVDs. CR improves glucose regulation, decreases blood pressure, and reduces circulating inflammatory molecules in rodents [9,14-17]. However, due to the differences in dietary regimes employed by different groups, the effects of CR on blood cholesterol are circumstantial [18-20]. In the absence of a reduction in cholesterol intake, CR does not alter serum cholesterol level in rodents. Nevertheless, an elevated high density lipoprotein-phospholipids/total phospholipids (HDL-PL/T-PL) ratio is still observed, suggesting an enhanced reverse cholesterol transport in calorie-restricted mice [20]. In non-human primates, it was observed that $\mathrm{CR}$ could decrease body weight, induces a better serum lipid profile, and improves insulin sensitivity [4,6,21-23]. Consistently, CR also reduces the risk of vascular diseases in humans. Clinical trials of the effects of 6 or 12 months of $\mathrm{CR}$ in non-obese humans revealed that short-term CR can effectively induce a better blood lipid profile, improve insulin sensitivity, and reduce C-reactive protein (CRP), a marker of inflammation [24-26]. Data obtained from eight subjects participated in the two-year ecological experiment "Biosphere 2" showed that CR with a low-protein diet can reduce various risk factors for vascular diseases [27]. The effects of long-term CR were examined by studies on 18 members from Calorie Restriction Society who had been on CR diet for an average of six years. Compared with age-matched individuals on western diet, the members of CR Society showed a remarkable reduction in the risk factors for vascular diseases, including lower levels of plasma total cholesterol, low-density lipoprotein- cholesterol (LDL-cholesterol), fasting glucose, and lower blood pressure [28].

Excessive calorie intake results in insulin resistance and an abnormal distribution of lipid, which is characterized by adipocyte expansion, lipid accumulation in liver and skeletal muscle, and hyperlipidemia [29-31]. On the contrary, a restriction of calorie intake makes the body to utilize the energy more efficiently and leads to a reduction of various metabolic factors that are associated with increased CVD risk. In adapting to $\mathrm{CR}$, fatty acid $\beta$-oxidation in liver and skeletal muscle is activated, thereby decreasing triglyceride accumulation in these tissues [32,33]. Insulin-stimulated glucose uptake in skeletal muscle is also enhanced by $\mathrm{CR}$, contributing to an improved glucose regulatory function [34,35]. Furthermore, CR reprograms lipid metabolism in adipocyte. Lipogenesis and the sensitivity to lipogenic/lipolytic stimuli of adipocytes are enhanced by $\mathrm{CR}$ [36,37]. CR also improves cardiac function in mice by promoting glucose oxidation [38]. These metabolic alterations in the liver, skeletal muscle, adipose tissue, and heart under CR condition coordinately lead to a lower body mass, improved insulin sensitivity, and a better blood lipid profile, which are beneficial for vascular homeostasis.

\subsection{CR improves local vascular function}

CR retards age-related functional decline of various organs, including the liver, skeletal muscle, and brain [3], and accumulating studies have also demonstrated its beneficial effects on vasculature. Decreased incidence of CVDs in calorie-restricted rhesus monkeys is observed [4]. Results from the study on 11 obese patients showed that a low-calorie diet is an effective treatment for essential hypertension [39]. Because of the difficulties in conducting experiments on humans, most of the studies of CR on vascular function/diseases have been carried out in rodents. These animal studies have revealed that CR could improve local vascular function via reducing oxidative stress, reserving nitric oxide (NO) bioactivity, and inhibiting vascular inflammation [8-11,40-42].

Increased reactive oxygen species (ROS) in vessel wall, which eventually culminates with oxidative stress, is strongly implicated in the development of many vascular diseases such as hypertension, atherosclerosis, and abdominal aortic aneurysm (AAA) [43-45]. Oxidative stress induces lipid peroxidation, protein oxidation, and mitochondrial and nuclear DNA damage, which leads to the activation of redox-sensitive transcription factors and the expression of pro-inflammatory genes [46]. CR attenuates vascular NADPH oxidase (NOX)-dependent ROS production in vasculature by inhibiting both the activity and the expression of NOX $[41,42,47]$. CR can also reduce mitochondrial ROS generation in the aortas of diabetic rats [9]. Furthermore, CR enhances the anti-oxidative defenses in the vascular system by upregulating the expression and activity 
of SOD and catalase [40-42]. Increased glutathione and ascorbate were also observed in the aortas of CR rats [48].

$\mathrm{NO}$ is an endogenous vasodilator which can not only stimulate VSMC dilation, but also inhibit platelet adherence and VSMC proliferation, and decrease the expression of pro-inflammatory genes [46]. The reduction of NO bioactivity is closely related to oxidative stress: NO can be inactivated by the ROS superoxide $\left(\mathrm{O}_{2}^{-}\right)$, and the predominant NO-generating enzyme in vessels, endothelial $\mathrm{NO}$ synthase (eNOS), will generate $\mathrm{O}_{2}^{-}$instead of $\mathrm{NO}$ when its function is impaired [49]. In rodents, CR can enhance NO bioactivity and ameliorate endothelial function through upregulating the expression and activity of eNOS, which is revealed as an increase in phospho-eNOS/total-eNOS ratio $[8,40-42,47]$.

Inflammation is a common pathophysiological state observed in vascular diseases [50,51]. CR retards vascular inflammation not only by decreasing systemic inflammation, but also by enhancing the anti-inflammatory function of the local vessel. In rats, CR reduces inflammatory markers in plasma, such as soluble adhesion molecules and CRP [16]. Human coronary arterial endothelial cells (CAECs) treated with serum from $\mathrm{CR}$ rats present suppressed nuclear factor $\kappa \mathrm{B}(\mathrm{NF}-\kappa \mathrm{B})$ activity [48], suggesting the lower inflammatory status of $\mathrm{CR}$ serum. ECs obtained from $\mathrm{CR}$ mice showed reduced sensitivity to oxidized low-density lipoprotein (ox-LDL), decreased expression of adhesion molecules and less mononuclear cell adhesion [52], implying that local vascular cells have enhanced anti-inflammatory capacity under CR conditions.

In order to maximize the energy obtained from a limited food source, the body reprograms energy metabolism, and the metabolic alterations in the liver, skeletal muscle, adipose tissue and heart lead to an improved function of these organs during CR. But whether CR also reprograms the metabolism of the vascular system remains unclear. Inflammation and oxidative stress are common features of vascular diseases, and they are closely related to the conversion of metabolic state [53]. Aberrant metabolic states of vascular lesions were observed in human and experimental animals [54-57]. Though not thoroughly studied, the present evidences strongly suggest that the metabolic switch is another key trait of aberrant vascular homeostasis. Therefore, we deduce that CR may modulate the metabolic state of vasculature and subsequently reduce inflammation and oxidative stress.

Taken together, CR guards vascular homeostasis by reducing systemic risk factors and improving local vascular functions (Figure 1). CR alters the metabolic state of various organs, including the liver, skeletal muscle, adipose tissue, and heart, thus reducing vascular risk factors. CR also retards the pathological changes of vascular diseases, such as oxidative stress and inflammation, but whether these effects are achieved through reprogramming the metabolism of the vasculature awaits further investigation.

\section{CR-responsive pathways in the regulation of vascular homeostasis}

Coordinated alterations in gene expression involved in energy metabolism are indicative of metabolic reprogramming and have been shown to be a prominent feature of CR [58,59]. The contributions of CR to vascular homeostasis,

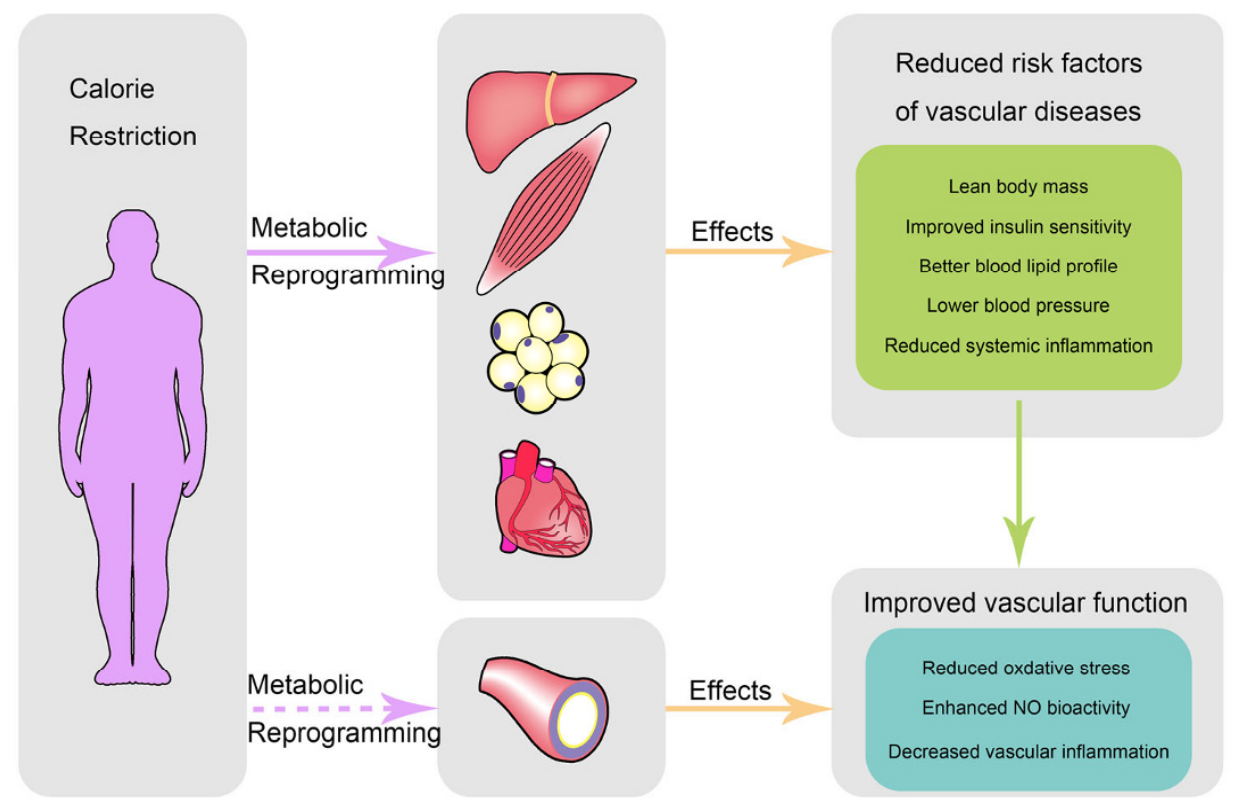

Figure 1 (color online) Calorie restriction preserves vascular homeostasis. CR alters the metabolic state of various organs, including the liver, skeletal muscle, adipose tissue and heart, thereby reducing vascular risk factors. Evidence from various recent studies suggests that CR may also retard the pathological changes of vascular diseases through reprogramming the metabolism of local vessels. 
including reduced systemic risk factors and improved local vascular functions, are speculated to be achieved by its function of metabolic reprogramming. Energy-sensing molecules, such as sirtuins, AMP-activated protein kinase (AMPK), and mammalian target of rapamycin (mTOR), can sense the lower energy state caused by reduced calorie intake $[60,61]$. Therefore, sirtuins, AMPK, mTOR and their regulating pathways play essential roles in mediating the effects of CR. Recent studies also revealed that eNOS plays an important role in modulating whole-body metabolism in response to reduced calorie intake besides its well-known direct role on vascular function.

Here, we summarize the evidence that sirtuins, AMPK, mTOR and eNOS mediate the effects of CR with particular attention paid on their regulatory function on local vascular functions. We then deduce their potential roles in mediating the effects of $\mathrm{CR}$ on vascular homeostasis.

\subsection{Sirtuins}

The mammalian sirtuin family (comprised of seven proteins from SIRT1 to SIRT7) is named after the yeast ortholog of Sir2 (silent information regulator 2), whose enzymatic activity requires $\mathrm{NAD}^{+}$as a substrate. Calorie restriction increases the intracellular $\mathrm{NAD}^{+} / \mathrm{NADH}$ ratio, and Sir2 is required for $\mathrm{CR}$ to extend lifespan in lower organisms [62-66].

\subsubsection{SIRT1}

SIRT1 participates in regulating a wide variety of biological processes, and many studies have shown that SIRT1 plays a critical protective role in modulating vascular functions via deacetylating different substrates including histones, transcription factors and other proteins (Table 1).

As an interface between the circulating blood and the vascular wall, ECs confront various stimuli, including disturbed shear stress, cytokines and modified lipoproteins. These stimuli can induce oxidative stress, impair NO bioavailability and induce the expression of adhesion molecules which further recruit and activate mononuclear cells transmigrating into the vascular wall. SIRT1 plays an important role in regulating endothelial function, including ROS production, NO production, inflammatory molecules expression, cell senescence and growth. Via suppressing the expression of p66Shc, a protein participates in the generation of mitochondrial ROS, and upregulating the expression of antioxidant enzymes, including MnSOD and catalase, the activation of SIRT1 reduces ROS production and enhances the resistance to oxidative stress in ECs $[67,68]$. Furthermore, SIRT1 enhances eNOS activity and promotes the production of NO by directly deacetylating eNOS and indirectly activating the liver kinase B1 (LKB1)-AMPK-eNOS signaling pathway [69-71]. Many studies also revealed that SIRT1 has anti-inflammatory effects in ECs by suppressing the transcriptional activity of NF- $\kappa \mathrm{B}$ and nuclear factor of activated T cells (NFAT), and subsequently decreasing the expression of inflammatory molecules [72-75]. Moreover, SIRT1 inhibits endothelial cell senescence [76-82], a process involved in endothelial dysfunction and atherogenesis

Table 1 List of described SIRT1 substrates in vascular cells, their downstream molecules, and the result of SIRT1 activation ${ }^{\text {a) }}$

\begin{tabular}{|c|c|c|c|c|c|}
\hline Cell type & \multicolumn{2}{|c|}{ Substrate } & Downstream molecules & Result of SIRT1 activation & References \\
\hline \multirow{10}{*}{$\mathrm{EC}$} & \multirow{2}{*}{ Histone } & H3 & p66Shc & Reduces ROS & [67] \\
\hline & & $\mathrm{H} 4$ & PAI-1 & Prevents cell senescence & [82] \\
\hline & \multirow{5}{*}{$\begin{array}{l}\text { transcription } \\
\text { factor }\end{array}$} & FoxO3a/PGC-1 $\alpha$ & MnSOD, Catalase & Reduces ROS & {$[68]$} \\
\hline & & NFAT & COX -2 & Reduces inflammation & [72] \\
\hline & & p65 & $\begin{array}{l}\text { ICAM-1, VCAM-1, CD40, } \\
\text { E-selectin }\end{array}$ & Reduces inflammation & {$[73-75]$} \\
\hline & & p53 & $\mathrm{p} 21$ & Prevents cell senescence & {$[76-80]$} \\
\hline & & FOXO1 & & Prevents cell senescence & [79] \\
\hline & \multirow{3}{*}{ others } & eNOS & & Increases NO production & {$[70,71]$} \\
\hline & & LKB1 & & Enhances eNOS activity, Prevents cell senescence & {$[69,81]$} \\
\hline & & NICD & & Promotes blood vessel growth & [84] \\
\hline \multirow{5}{*}{ VSMC } & \multirow{4}{*}{$\begin{array}{l}\text { transcription } \\
\text { factor }\end{array}$} & FoxO1 & SIRT1 & Promotes SIRT1 expression & {$[85]$} \\
\hline & & p53 & p21 & Prevents cell senescence & {$[87,88]$} \\
\hline & & p65 & TGF- $\beta$ & Suppresses vascular remodeling & [89] \\
\hline & & RFX5 & COL1A2 & Promotes collagen expression & [91] \\
\hline & others & NBS-1 & & Enhances DNA repair & {$[86]$} \\
\hline \multirow{2}{*}{ Macrophage } & \multirow{2}{*}{$\begin{array}{l}\text { transcription } \\
\text { factor }\end{array}$} & AP-1 & COX -2 & Reduces inflammation & {$[92]$} \\
\hline & & p65 & Lox-1,TNF- $\alpha$, IL- $1 \beta$, iNOS & Reduces ox-LDL uptake and inflammation & {$[93,94]$} \\
\hline
\end{tabular}

a) PAI-1, plasminogen-activator inhibitor-1; FoxO3a, forkhead box O3a; PGC-1 $\alpha$, peroxisome proliferator-activated receptor $\gamma$-coactivator $1 \alpha$; NFAT, nuclear factor of activated T cells; COX-2, cyclooxygenase-2; ICAM-1, intracellular adhesion molecule 1; VCAM-1, vascular adhesion molecule 1; FoxO1, forkhead box O1; LKB1, liver kinase B1; NICD, Notch1 intracellular domain; TGF- $\beta$, transforming growth factor $\beta$; AP-1, activator protein-1; MMP9, matrix metalloproteinase 9; RFX5, regulatory factor for X-box 5; COL1A2, collagen type I; NBS-1, Nijmegen Breakage Syndrom-1; Lox-1, lectin-like ox-LDL receptor 1 ; TNF- $\alpha$, tumor necrosis factor $\alpha$; IL-1 $\beta$, interleukin $1 \beta$; iNOS, inducible nitric oxide synthase. 
[83], via deacetylating a variety of substrates. It was also found that lacking SIRT1 in ECs causes impaired cell growth and vascular branching as a result of the hyper-acetylated Notch1 intracellular domain (NICD) and enhanced Notch signaling, indicating the importance of SIRT1 in regulating endothelial growth [84].

Pathological changes of VSMCs, including apoptosis, senescence, proliferation and migration, contribute to vascular diseases such as atherosclerosis, post-stent stenosis and hypertension. SIRT1 plays an important role in regulating the function and behavior of VSMCs [85-91]. SIRT1 deacetylates and activates the DNA repair protein Nijmegen Breakage Syndrom-1 (NBS-1), enhancing VSMCs' resistance to apoptosis caused by oxidative stress [86]. Via suppressing p53 and p21, the activation and overexpression of SIRT1 also prevents the senescence of VSMCs $[87,88]$. In addition, SIRT1 suppresses VSMC migration, proliferation and vascular remodeling by deacetylating a number of transcription factors and modulating the expression of their downstream molecules [89-91].

The infiltration of macrophages into the vascular wall is a key event of vascular inflammation. By modulating macrophage function, SIRT1 suppresses vascular inflammation. Overexpression of SIRT1 in macrophages helps to dampen macrophage function via inhibiting activator protein 1 (AP-1) and NF- $\kappa \mathrm{B}$ activity and the expression of inflammatory molecules, such as cyclooxygenase-2 (COX-2) and tumor necrosis factor $\alpha(\mathrm{TNF}-\alpha)$ [92,93]. Moreover, by deacetylating RelA/p65, a subunit of NF- $\mathrm{B}$, SIRT1 diminishes lectin-like ox-LDL receptor 1 (Lox-1) expression in macrophages, thereby reducing ox-LDL uptake and preventing foam cell formation and atherosclerosis in mice [94].

Many scientific evidences demonstrated that SIRT1 mediates the effects of CR in mammals. First, CR increases the expression of SIRT1. In rodents, CR upregulates SIRT1 protein levels in many tissues, including the liver [95], brain [95,96], kidney [95], white and brown adipose tissue [95,97], intestine [98], and the aorta [41,42,48,99]. CR also increases SIRT1 gene expression in skeletal muscles of healthy humans [100]. Reciprocally, a high-fat diet leads to the loss of SIRT1 in adipose tissue of mice [101], and downregulated expression of SIRT1 in adipose tissue was also observed in obese people [102,103]. Second, loss of SIRT1 ablated the outputs of CR. Mice deficient in SIRT1 fail to display some of the responses normally triggered by CR [104]. Moreover, the longevity-promoting effect of CR is blunted in mice lacking SIRT1 [105]. Third, SIRT1 transgenic mice exhibit phenotypes resembling CR: they are leaner and more active than littermate controls, and they have reduced blood cholesterol and improved glucose regulatory function [106]. Furthermore, SIRT1 reprograms the metabolism of the liver, skeletal muscle, and adipose tissue; thereby mitigating diabetes, obesity and hepatic steatosis [107-110]. These effects of SIRT1 resemble closely the effects of CR. Therefore, the activation of SIRT1 by CR triggers a metabolic switch contributing to a lower risk for vascular diseases. Researches also suggest that the upregulation of SIRT1 in vascular cells contributes to the benefits of CR. Treatment of CAECs with serum from CR rats attenuated TNF- $\alpha$-induced ROS generation and NF- $\kappa \mathrm{B}$ activity, while these effects of $\mathrm{CR}$ serum were mitigated by knockdown of SIRT1 [48]. CR also leads to deacetylation of eNOS and enhances NO production in mouse aorta, which is at least in part via the activation of SIRT1 $[41,47,71]$. The effects of SIRT1 in ECs, VSMCs and macrophages may also help explaining the protective role of CR against atherosclerosis and endothelial dysfunction [11,42].

In summary, SIRT1 reprograms whole-body metabolism in response to $\mathrm{CR}$, and also mediates the benefits of $\mathrm{CR}$ on vascular function. However, its role in modulating vascular cell metabolism remains unknown and deserves further investigation.

\subsubsection{SIRT3}

Among the sirtuins, the mitochondrial sirtuin SIRT3 is most similar in sequence to SIRT1 [111]. SIRT3 plays a key role in regulating systemic metabolism by deacetylating a wide range of metabolic enzymes in mitochondria [112,113]. However, studies have showed no obvious vascular dysfunction in SIRT3 ${ }^{-/}$mice. SIRT3 deletion does not augment hypoxia-induced ROS signaling or the development of pulmonary artery hypertension in mice [114]. SIRT3 deficiency in $L D L$ receptor ${ }^{-/}\left(L D L R^{-/}\right)$mice results in increases in body weight, plasma glucose level and systemic oxidative stress, but does not accelerate the vascular oxidative stress or the development of atherosclerosis [115]. These findings suggest a potential role of SIRT3 in the development of cardiovascular risk factors and a function of postponing the onset of distinct metabolic risk factors.

SIRT3 also functions as a prominent regulator in CR adaptation. CR upregulates SIRT3 expression in many metabolic active tissues such as the liver, skeletal muscle, and brown and white adipose tissue [116-118]. Moreover, SIRT3 mediates many of the CR's outputs on the regulation of metabolism and oxidative stress, which are supported by evidences derived from SIRT3 ${ }^{-/}$mice. Via deacetylating long-chain acyl-CoA dehydrogenase (LCAD), HMGCS2, and ornithine transcarbamoylase (OTC), SIRT3 increases fatty acid oxidation, amino acid catabolism and ketone body production under CR and fasting conditions [118-120]. Furthermore, in response to CR, SIRT3 deacetylates and activates SOD2 and isocitrate dehydrogenase 2 (IDH2), leading to reduced oxidative stress [121,122]. Acetyl-proteinomic studies further show that CR dramatically alters the mitochondrial protein acetylome, which is partly mediated by activation of SIRT3 [59].

Altogether, SIRT3 is a key molecule that controls the systemic metabolism and oxidative stress, and activation of 
SIRT3 under CR leads to metabolic reprogramming. SIRT3 deacetylates and activates SOD in liver and adipose tissue of mice under CR [121]. Enhanced activity of SOD in aorta was also observed in CR mice [40-42]. Therefore, it is possible that the activation of SOD in aorta under CR is also obtained through the activation of SIRT3. Although deletion of SIRT3 in $L D L R^{-/-}$mice does not result in any exacerbation of vascular oxidative stress [115], we should not rule out the possibility that SIRT3 could regulate vascular oxidative stress under other circumstances.

Compared with SIRT1 and SIRT3, other sirtuins, which also sense $\mathrm{NAD}^{+} / \mathrm{NADH}$ levels, are involved in the regulation of metabolism as well $[123,124]$. Whether they are indispensible for the influence of CR is still unclear [125]. Furthermore, little is known about their function in the vascular system. More studies are needed to determine their physiology in vascular homeostasis and CR.

\subsection{AMPK}

AMP-activated protein kinase (AMPK) is a heterotrimeric kinase composed of a catalytic $(\alpha)$ and two regulatory $(\beta$ and $\gamma$ ) subunits [126]. The activation of AMPK requires AMP to bind the $\gamma$ subunit first, and then the phosphorylation of Thr172 on the $\alpha$ subunit to fully activate the enzyme [126]. Once activated, AMPK turns on catabolic pathways to restore ATP levels by promoting glycolysis and fatty acid oxidation and by increasing mitochondrial contents [126]. AMPK is a key sensor and effector of energy status [126], and plays an critical role the regulation of metabolic processes [127]. Furthermore, AMPK is also involved in the regulation vascular function [128].

AMPK plays an essential role in improving endothelial function through regulating eNOS activity, redox status, and lipid metabolism [129]. AMPK activates eNOS and enhances NO bioactivity in ECs by phosphorylating eNOS [130-132]. Loss of AMPKa1 in HUVECs leads to decreased expression of anti-oxidative enzymes, reduced mitochondrial content and increased sensitivity to oxidative stress [133]. On the contrary, activation of AMPK in HUVECs induces mitochondrial biogenesis and enhances the resistance to $\mathrm{H}_{2} \mathrm{O}_{2}$ [134]. Furthermore, it has been proven that in bovine aortic endothelial cells (BAECs), HAECs and HUVECs, activation of AMPK increases fatty acids oxidation and subsequently reduces hyperglycemia- and linoleic acid-induced cell apoptosis [135-137].

AMPK regulates VSMC function and behavior as well, but different isoforms of AMPK $\alpha$ function differently. Activation of AMPK $\alpha 1$, but not AMPK $\alpha 2$, is able to induce endothelium- and eNOS-independent aortic relaxation in mice [138]. Deletion of AMPK $\alpha 2$ - but not AMPK $\alpha 1$ - in mice aggravates VSMCs proliferation and neointima formation after mechanical arterial injury [139]. Conversely, in Angiotensin II-induced AAAs, AMPK $\alpha 2$ activation in VSMCs promotes the degradation of tunica media [140].
AMPK also participates in controlling macrophage function. Both genetic and pharmacological activation of AMPK in macrophages results in a decreased inflammatory response, whereas suppressing AMPK increases the secretion of pro-inflammatory factors by macrophages in vitro [141-143]. AMPK $\alpha 1$ is crucial for the phenotype transition of macrophages in vivo [144]. Moreover, activation of AMPK $\beta 1$ reduces macrophage inflammation by enhancing fatty acid oxidation [145].

AMPK is required for many of the adaptations triggered by $\mathrm{CR}$ in lower eukaryotes, including lifespan extension [146-148]. In rodents, CR increases the phosphorylation of AMPK $\alpha$ in heart and skeletal muscle [14,149-151]. In addition, many beneficial effects of $\mathrm{CR}$ will be abrogated when using AMPK inhibitor to rodents. These effects include protecting hearts from ischemia/reperfusion injury $[150,151]$, preventing hypertension-induced cardiac hypertrophy [14], and promoting revascularization in ischemic muscle [149]. Therefore, AMPK is a sensor and an effector of CR in mammals as well.

AMPK activates and coordinates with SIRT1, the key mediator of CR. First, upon glucose restriction, AMPK activates SIRT1 through the upregulation of nicotinamide phosphoribosyltransferase (Nampt) expression and subsequent increased $\mathrm{NAD}^{+} / \mathrm{NADH}$ ratio [152]. SIRT1 also activates AMPK through deacetylating LKB1, the kinase upstream of AMPK [107,153-155]. In addition, AMPK and SIRT1 function synergistically to activate their common substrates. The phosphorylation of peroxisome proliferator-activated receptor $\gamma$-coactivator $1 \alpha(\mathrm{PGC}-1 \alpha)$ and eNOS by AMPK is required for their following deacetylation by SIRT1 [70,156]. It is also noted that SIRT3 and AMPK act coordinately. AMPK can activate SIRT3 by regulating the $\mathrm{NAD}^{+} / \mathrm{NADH}$ ratio [157], and conversely, SIRT3 can also activate AMPK by deacetylating LKB1 $[116,158]$.

In summary, the activation of AMPK mediates many effects of CR. The influence of AMPK on the metabolism and energy balance at the whole-body level may provide a lower risk for vascular diseases, and the function of AMPK in ECs and macrophages may help to explain the protective roles of $\mathrm{CR}$ in atherosclerosis and in endothelial dysfunction. However, the activation of AMPK in VSMCs can play protective or detrimental roles in different diseases $[139,140]$. Thus far, no direct evidence has been observed about the expression and activity of AMPK in aortas in response to CR. Increased phosphorylation of eNOS has been observed in the aortas of CR mice [8], which may be due to the activation of AMPK [131,159], while further studies are still required to elucidate whether (and how) CR regulates local vascular AMPK activity.

\section{3 mTOR}

mTOR is a serine/threonine protein kinase activated by environmental cues, such as growth factors, nutrients, energy 
and stress [61,160]. Activation of the mTOR signaling pathway promotes cell growth and division by inducing anabolic metabolism. mTOR functions in two distinct complexes: mTOR complex 1 (mTORC1), which is rapamycin-sensitive, and mTOR complex 2 (mTORC2), which is affected only indirectly by rapamycin $[61,160]$.

The mTOR signaling pathway plays an important role in the regulation of vascular homeostasis. Inhibition of mTOR signaling can attenuate the proliferation and migration of VSMCs [161]. In this manner, everolimus-eluting coronary stent markedly prevents the development of in-stent restenosis in humans [162]. Similarly, 40-O-(2-hydroxyethyl)rapamycin also attenuates pulmonary artery hypertension in rodents [163]. The mTOR signaling pathway is involved in the regulation of vascular oxidative stress and inflammation as well. Silencing ribosomal S6 protein kinase 1 (S6K1), a component of mTOR signaling pathway, reduces oxidative stress and enhances NO production in senescent HUVECs [164]. In addition, knockdown or pharmacological attenuation of mTOR has been shown to prevent atherogenesis by inhibiting macrophage chemotaxis and the expression of inflammatory molecules in mice [165-169].

Attenuated mTOR signaling is thought to play a part in mediating longevity and health benefits in response to $\mathrm{CR}$ [170,171]. CR acts through inhibiting mTOR to regulate lifespan of yeast, worms and flies [172-176]. Pharmacological or genetic disruption of mTORC1 or S6K1 is sufficient to extend lifespan of mice as well [177-180]. Moreover, deletion of S6K1 is able to not only activate AMPK, but also induce a gene expression pattern similar to that seen in CR [180,181]. Inhibition of mTORC1 confers protection against a growing list of age-related pathologies, including obesity, metabolic diseases, neurodegenerative diseases, and cancer [170], and these effects are similar to the effects of CR. Furthermore, mTOR signaling pathway is suppressed by AMPK and SIRT1, which are key molecules in response to CR [182-184].

Increased mTOR signaling has been observed in the aortas of old mice or mice fed with a high-fat diet $[41,185]$. Conversely, CR inhibits mTOR activity in mouse aortas [41]. However, there is still no evidence proving that CR improves vascular function through inhibiting mTOR activity. More researches shall be made on the role of mTOR in $\mathrm{CR}$ and vascular homeostasis.

\section{4 eNOS}

The molecules discussed above, which sense the energy state, are widely accepted as molecules mediating CR's effects [186]. Although eNOS is less known for sensing the energy state, particular attention is paid to this molecule here because of its central role in modulating vascular function; and also for its emerging importance in the regulation of systemic metabolism under CR.

Endothelial NOS is essential for vascular NO production and ROS clearance, and many reviews have been published concerning the roles of eNOS in vascular homeostasis $[46,187,188]$. Besides, the importance of eNOS in modulating whole body metabolism and longevity has become more and more prominent. eNOS-knockout mice are hypertensive and insulin-resistant, and they have higher levels of blood cholesterol and triglyceride than wild type mice [189]. On the contrary, eNOS transgenic mice showed lower plasma triglyceride and fatty acids, elevated metabolic activity of adipose tissue and resistance to diet-induced obesity [190]. Furthermore, eNOS also plays an essential role in mediating the effects of CR. First, CR upregulates eNOS expression in the skeletal muscles of healthy humans [100], and also in the brain, liver, heart, and brown adipose tissue of mice [97]. Second, CR promotes mitochondrial biogenesis and SIRT1 expression in male mice, whereas these effects were strongly attenuated in eNOS null-mutant mice [97]. Third, the product of eNOS, NO, has been proved to be an endogenous activator of SIRT1 and AMPK [191-194].

eNOS is critical not only for regulating systemic metabolic state, but also for modulating local vascular function in response to CR. Both life-long and short-term CR enhances arterial eNOS expression and improves endothelium-dependent vascular relaxation in rodents $[9,41,42,47]$. In addition, enhanced phospho-eNOS (Ser1177) and reduced acetyl-eNOS were also observed in CR mice [8,71], implying the modulation of eNOS by AMPK and SIRT1. Even though, there is still no direct evidence proving the necessity of eNOS in realizing the protective effects of CR on vascular homeostasis.

\section{Conclusion and perspectives}

In summary, sirtuins, AMPK, mTOR and eNOS and their regulatory pathways are all essential pathways which might mediate CR's effects on vascular homeostasis. CR lowers nutrient supplies and raises $\mathrm{NAD}^{+} / \mathrm{NADH}$ and AMP levels, thereby inhibiting mTOR pathway and activating sirtuins and AMPK. CR also upregulates eNOS, despite that the mechanism is still unknown. AMPK activates SIRT1 and SIRT3 through the upregulation of $\mathrm{NAD}^{+}$-to-NADH ratio, while SIRT1 and SIRT3 also activates AMPK via deacetylating LKB1, the AMPK kinase. SIRT1 and AMPK functions coordinately to activate eNOS, and on the other way around, the eNOS product, NO, could activate SIRT1 and AMPK. Moreover, SIRT1 and AMPK could also inhibit mTOR pathway (Figure 2). These molecules and their regulatory pathways play essential roles not only in regulating the whole-body metabolism, but also in modulating vascular function. Evidences from recent studies suggest that by fine-tuning the activities of sirtuins, AMPK, eNOS, and mTOR, CR contributes to reduced systemic risk factors and improved vascular homeostasis. Drugs targeting these molecules, such as resveratrol, metformin and rapamycin, also 


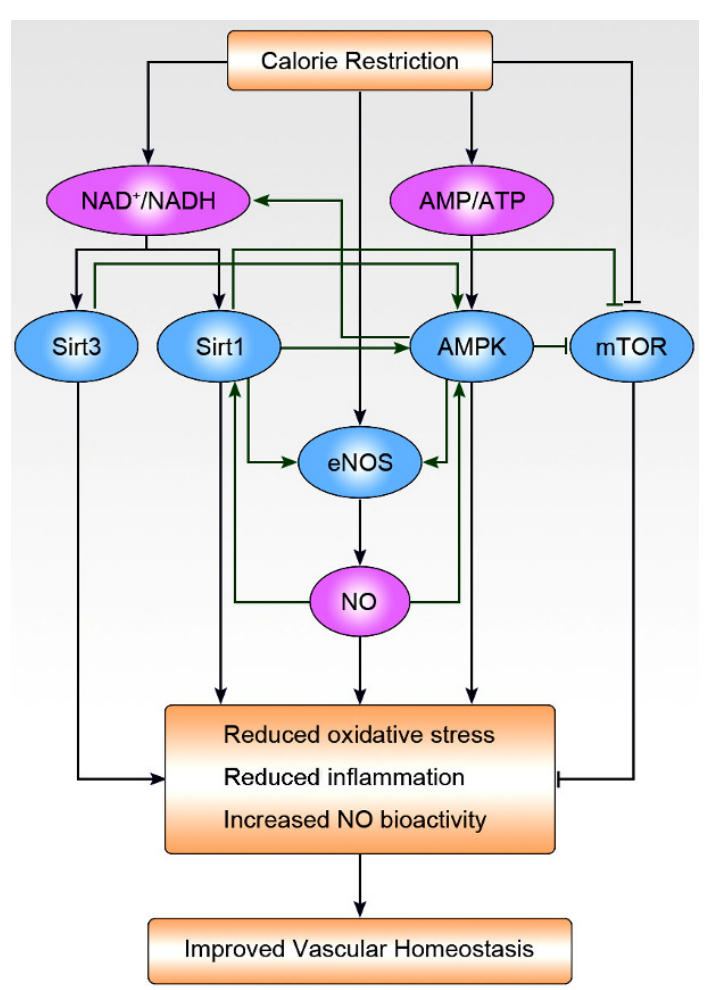

Figure 2 (color online) Molecular pathways which might mediate the effects of $\mathrm{CR}$ on vascular homeostasis. CR lowers nutrient supplies and raises $\mathrm{NAD}^{+} / \mathrm{NADH}$ and $\mathrm{AMP}$ levels, thereby inhibiting the mTOR signaling pathway and activating sirtuins and AMPK. CR also upregulates eNOS, but the mechanism is still unkown. AMPK activates SIRT1 and SIRT3 through the upregulation of $\mathrm{NAD}^{+}$-to-NADH ratio, while SIRT1 and SIRT3 also activates AMPK via deacetylating LKB1, the AMPK kinase. SIRT1 and AMPK function coordinately to activate eNOS. Conversely, the eNOS product, NO, could activate Sirt1 and AMPK. Moreover, SIRT1 and AMPK could also inhibit the mTOR pathway. By fine-tuning the activities of sirtuins, AMPK, eNOS and mTOR, CR contributes to improved vascular homeostasis.

showed their promising benefits on vascular homeostasis. However, the exact roles of these molecules in local vasculature in response to $\mathrm{CR}$ remain unclear and need further investigation. As the employment of CR in human would be hampered by its harsh criteria and long time, targeting these pathways would be more practical for therapeutic uses. Thus, studies on CR not only provide us a life style model good for vascular health, but also open new avenues for searching molecular targets for the treatment of vascular diseases.

CR reprograms metabolism, reduces risk factors for CVDs and maintains vascular homeostasis in experimental animals as well as in humans. Studies in rodents have further yielded with concrete results that CR improves vascular homeostasis via modulating a broad spectrum of pathophysiological processes. However, larger, well-controlled clinical studies are required to determine the efficacy of CR in patients in preventing and treating vascular diseases. Moreover, the effects of CR on vascular metabolism are still an open question.
We thank Zhang Ran and Fu WenYan (State Key Laboratory of Medical Molecular Biology, Department of Biochemistry and Molecular Biology, Institute of Basic Medical Sciences, Chinese Academy of Medical Sciences \& Peking Union Medical College) for critically reading this manuscript. This work was supported by the National Natural Science Foundation of China (31271227, 91339201), the Beijing Nova Program (XX2013064), and the National Basic Research Program of China (2011CB503902).

1 Piper MD, Bartke A. Diet and aging. Cell Metab, 2008, 8: 99-104

2 McCay CM, Crowell MF, Maynard LA. The effect of retarded growth upon the length of life span and upon the ultimate body size. 1935. Nutrition, 1989, 5: 155-171; discussion 172

3 Fontana L, Partridge L, Longo VD. Extending healthy life spanfrom yeast to humans. Science, 2010, 328: 321-326

4 Colman RJ, Anderson RM, Johnson SC, Kastman EK, Kosmatka KJ, Beasley TM, Allison DB, Cruzen C, Simmons HA, Kemnitz JW, Weindruch R. Caloric restriction delays disease onset and mortality in rhesus monkeys. Science, 2009, 325: 201-204

5 Colman RJ, Beasley TM, Kemnitz JW, Johnson SC, Weindruch R, Anderson RM. Caloric restriction reduces age-related and all-cause mortality in rhesus monkeys. Nat Commun, 2014, 5: 3557

6 Mattison JA, Roth GS, Beasley TM, Tilmont EM, Handy AM, Herbert RL, Longo DL, Allison DB, Young JE, Bryant M, Barnard D, Ward WF, Qi W, Ingram DK, de Cabo R. Impact of caloric restriction on health and survival in rhesus monkeys from the NIA study. Nature, 2012, 489: 318-321

7 World Health Organizaton: The top 10 causes of death. 2013, http://www.who.int/mediacentre/factsheets/fs310/en/

8 Ketonen J, Pilvi T, Mervaala E. Caloric restriction reverses high-fat diet-induced endothelial dysfunction and vascular superoxide production in C57B1/6 mice. Heart Vessels, 2010, 25: 254-262

9 Minamiyama Y, Bito Y, Takemura S, Takahashi Y, Kodai S, Mizuguchi S, Nishikawa Y, Suehiro S, Okada S. Calorie restriction improves cardiovascular risk factors via reduction of mitochondrial reactive oxygen species in type II diabetic rats. J Pharmacol Exp Ther, 2007, 320: 535-543

10 Castello L, Froio T, Cavallini G, Biasi F, Sapino A, Leonarduzzi G, Bergamini E, Poli G, Chiarpotto E. Calorie restriction protects against age-related rat aorta sclerosis. FASEB J, 2005, 19: 1863-1865

11 Guo Z, Mitchell-Raymundo F, Yang H, Ikeno Y, Nelson J, Diaz V, Richardson A, Reddick R. Dietary restriction reduces atherosclerosis and oxidative stress in the aorta of apolipoprotein E-deficient mice. Mech Ageing Dev, 2002, 123: 1121-1131

12 Strom A, Jensen RA. Mortality from circulatory diseases in Norway 1940-1945. Lancet, 1951, 1: 126-129

13 Willcox BJ, Willcox DC, Todoriki H, Fujiyoshi A, Yano K, He Q, Curb JD, Suzuki M. Caloric restriction, the traditional Okinawan diet, and healthy aging: the diet of the world's longest-lived people and its potential impact on morbidity and life span. Ann N Y Acad Sci, 2007, 1114: 434-455

14 Dolinsky VW, Morton JS, Oka T, Robillard-Frayne I, Bagdan M, Lopaschuk GD, Des Rosiers C, Walsh K, Davidge ST, Dyck JR. Calorie restriction prevents hypertension and cardiac hypertrophy in the spontaneously hypertensive rat. Hypertension, 2010, 56: 412-421

15 Zou Y, Jung KJ, Kim JW, Yu BP, Chung HY. Alteration of soluble adhesion molecules during aging and their modulation by calorie restriction. FASEB J, 2004, 18: 320-322

16 Kalani R, Judge S, Carter C, Pahor M, Leeuwenburgh C. Effects of caloric restriction and exercise on age-related, chronic inflammation assessed by C-reactive protein and interleukin-6. J Gerontol A Biol Sci Med Sci, 2006, 61: 211-217

17 Dean DJ, Gazdag AC, Wetter TJ, Cartee GD. Comparison of the effects of 20 days and 15 months of calorie restriction on male Fischer 344 rats. Aging (Milano), 1998, 10: 303-307

18 Wang Z, Masternak MM, Al-Regaiey KA, Bartke A. Adipocytokines and the regulation of lipid metabolism in growth hormone transgenic 
and calorie-restricted mice. Endocrinology, 2007, 148: 2845-2853

19 Lijnen HR, Van Hul M, Hemmeryckx B. Caloric restriction improves coagulation and inflammation profile in obese mice. Thromb Res, 2012, 129: 74-79

20 Stein O, Dabach Y, Halperin G, Ben-Naim M, Stein Y. Calorie restriction in mice does not affect LDL reverse cholesterol transport in vivo. Biochem Biophys Res Commun, 2003, 308: 29-34

21 Verdery RB, Ingram DK, Roth GS, Lane MA. Caloric restriction increases HDL2 levels in rhesus monkeys (Macaca mulatta). Am J Physiol, 1997, 273: E714-719

22 Cefalu WT, Terry JG, Thomas MJ, Morgan TM, Edwards IJ, Rudel LL, Kemnitz JW, Weindruch R. In vitro oxidation of low-density lipoprotein in two species of nonhuman primates subjected to caloric restriction. J Gerontol A Biol Sci Med Sci, 2000, 55: B355-361

23 Lane MA, Tilmont EM, De Angelis H, Handy A, Ingram DK, Kemnitz JW, Roth GS. Short-term calorie restriction improves disease-related markers in older male rhesus monkeys (Macaca mulatta). Mech Ageing Dev, 2000, 112: 185-196

24 Lefevre M, Redman LM, Heilbronn LK, Smith JV, Martin CK, Rood JC, Greenway FL, Williamson DA, Smith SR, Ravussin E. Caloric restriction alone and with exercise improves CVD risk in healthy non-obese individuals. Atherosclerosis, 2009, 203: 206-213

25 Fontana L, Villareal DT, Weiss EP, Racette SB, Steger-May K, Klein S, Holloszy JO. Calorie restriction or exercise: effects on coronary heart disease risk factors. A randomized, controlled trial. Am J Physiol Endocrinol Metab, 2007, 293: E197-202

26 Weiss EP, Racette SB, Villareal DT, Fontana L, Steger-May K, Schechtman KB, Klein S, Holloszy JO. Improvements in glucose tolerance and insulin action induced by increasing energy expenditure or decreasing energy intake: a randomized controlled trial. Am J Clin Nutr, 2006, 84: 1033-1042

27 Walford RL, Mock D, Verdery R, MacCallum T. Calorie restriction in biosphere 2: alterations in physiologic, hematologic, hormonal, and biochemical parameters in humans restricted for a 2-year period. J Gerontol A Biol Sci Med Sci, 2002, 57: B211-224

28 Fontana L, Meyer TE, Klein S, Holloszy JO. Long-term calorie restriction is highly effective in reducing the risk for atherosclerosis in humans. Proc Natl Acad Sci USA, 2004, 101: 6659-6663

29 Klop B, Elte JW, Cabezas MC. Dyslipidemia in obesity: mechanisms and potential targets. Nutrients, 2013, 5: 1218-1240

30 Boden G. Obesity, insulin resistance and free fatty acids. Curr Opin Endocrinol Diabetes Obes, 2011, 18: 139-143

31 Perry RJ, Samuel VT, Petersen KF, Shulman GI. The role of hepatic lipids in hepatic insulin resistance and type 2 diabetes. Nature, 2014, 510: 84-91

32 Kim JY, Kim DH, Choi J, Park JK, Jeong KS, Leeuwenburgh C, Yu $\mathrm{BP}$, Chung HY. Changes in lipid distribution during aging and its modulation by calorie restriction. Age (Dordr), 2009, 31: 127-142

33 Zhu M, Miura J, Lu LX, Bernier M, DeCabo R, Lane MA, Roth GS, Ingram DK. Circulating adiponectin levels increase in rats on caloric restriction: the potential for insulin sensitization. Exp Gerontol, 2004, 39: 1049-1059

34 McCurdy CE, Cartee GD. Akt2 is essential for the full effect of calorie restriction on insulin-stimulated glucose uptake in skeletal muscle. Diabetes, 2005, 54: 1349-1356

35 Gazdag AC, Dumke CL, Kahn CR, Cartee GD. Calorie restriction increases insulin-stimulated glucose transport in skeletal muscle from IRS-1 knockout mice. Diabetes, 1999, 48: 1930-1936

36 Valle A, Sastre-Serra J, Roca P, Oliver J. Modulation of white adipose tissue proteome by aging and calorie restriction. Aging Cell, 2010, 9: 882-894

37 Linford NJ, Beyer RP, Gollahon K, Krajcik RA, Malloy VL, Demas V, Burmer GC, Rabinovitch PS. Transcriptional response to aging and caloric restriction in heart and adipose tissue. Aging Cell, 2007, 6: 673-688

38 Sung MM, Soltys CL, Masson G, Boisvenue JJ, Dyck JR. Improved cardiac metabolism and activation of the RISK pathway contributes to improved post-ischemic recovery in calorie restricted mice. J Mol Med (Berl), 2011, 89: 291-302
39 Sasaki S, Higashi Y, Nakagawa K, Kimura M, Noma K, Hara K, Matsuura H, Goto C, Oshima T, Chayama K. A low-calorie diet improves endothelium-dependent vasodilation in obese patients with essential hypertension. Am J Hypertens, 2002, 15: 302-309

40 Zanetti M, Gortan Cappellari G, Burekovic I, Barazzoni R, Stebel M, Guarnieri G. Caloric restriction improves endothelial dysfunction during vascular aging: Effects on nitric oxide synthase isoforms and oxidative stress in rat aorta. Exp Gerontol, 2010, 45: 848-855

41 Donato AJ, Walker AE, Magerko KA, Bramwell RC, Black AD, Henson GD, Lawson BR, Lesniewski LA, Seals DR. Life-long caloric restriction reduces oxidative stress and preserves nitric oxide bioavailability and function in arteries of old mice. Aging Cell, 2013, 12: 772-783

42 Rippe C, Lesniewski L, Connell M, LaRocca T, Donato A, Seals D. Short-term calorie restriction reverses vascular endothelial dysfunction in old mice by increasing nitric oxide and reducing oxidative stress. Aging Cell, 2010, 9: 304-312

43 Schulz E, Gori T, Munzel T. Oxidative stress and endothelial dysfunction in hypertension. Hypertens Res, 2011, 34: 665-673

44 Madamanchi NR, Vendrov A, Runge MS. Oxidative stress and vascular disease. Arterioscler Thromb Vasc Biol, 2005, 25: 29-38

45 McCormick ML, Gavrila D, Weintraub NL. Role of oxidative stress in the pathogenesis of abdominal aortic aneurysms. Arterioscler Thromb Vasc Biol, 2007, 27: 461-469

46 Forstermann U. Nitric oxide and oxidative stress in vascular disease. Pflugers Arch, 2010, 459: 923-939

47 Chou SH, Lee YC, Huang CF, Wang YR, Yu HP, Lau YT. Gender-specific effects of caloric restriction on the balance of vascular nitric oxide and superoxide radical. Cardiovasc Res, 2010, 87: 751-759

48 Csiszar A, Labinskyy N, Jimenez R, Pinto JT, Ballabh P, Losonczy G, Pearson KJ, de Cabo R, Ungvari Z. Anti-oxidative and anti-inflammatory vasoprotective effects of caloric restriction in aging: role of circulating factors and SIRT1. Mech Ageing Dev, 2009, 130: $518-527$

49 Forstermann U, Closs EI, Pollock JS, Nakane M, Schwarz P, Gath I, Kleinert H. Nitric oxide synthase isozymes. Characterization, purification, molecular cloning, and functions. Hypertension, 1994, 23: 1121-1131

50 Weber C, Noels H. Atherosclerosis: current pathogenesis and therapeutic options. Nat Med, 2011, 17: 1410-1422

51 Nordon IM, Hinchliffe RJ, Loftus IM, Thompson MM. Pathophysiology and epidemiology of abdominal aortic aneurysms. Nat Rev Cardiol, 2011, 8: 92-102

52 Yang H, Shi M, Story J, Richardson A, Guo Z. Food restriction attenuates age-related increase in the sensitivity of endothelial cells to oxidized lipids. J Gerontol A Biol Sci Med Sci, 2004, 59: 316-323

53 Ye J, Keller JN. Regulation of energy metabolism by inflammation: a feedback response in obesity and calorie restriction. Aging (Albany NY), 2010, 2: 361-368

54 Moustafa RR, Izquierdo-Garcia D, Fryer TD, Graves MJ, Rudd JH, Gillard JH, Weissberg PL, Baron JC, Warburton EA. Carotid plaque inflammation is associated with cerebral microembolism in patients with recent transient ischemic attack or stroke: a pilot study. Circ Cardiovasc Imag, 2010, 3: 536-541

55 Tawakol A, Migrino RQ, Hoffmann U, Abbara S, Houser S, Gewirtz $\mathrm{H}$, Muller JE, Brady TJ, Fischman AJ. Noninvasive in vivo measurement of vascular inflammation with F-18 fluorodeoxyglucose positron emission tomography. J Nucl Cardiol, 2005, 12: 294-301

56 Leppanen O, Bjornheden T, Evaldsson M, Boren J, Wiklund O, Levin M. ATP depletion in macrophages in the core of advanced rabbit atherosclerotic plaques in vivo. Atherosclerosis, 2006, 188: 323-330

57 Yamashita A, Zhao Y, Matsuura Y, Yamasaki K, Moriguchi-Goto S, Sugita C, Iwakiri T, Okuyama N, Koshimoto C, Kawai K, Tamaki N, Zhao S, Kuge Y, Asada Y. Increased metabolite levels of glycolysis and pentose phosphate pathway in rabbit atherosclerotic arteries and hypoxic macrophage. PLoS ONE, 2014, 9: e86426

58 Dhahbi JM, Mote PL, Wingo J, Rowley BC, Cao SX, Walford RL, 
Spindler SR. Caloric restriction alters the feeding response of key metabolic enzyme genes. Mech Ageing Dev, 2001, 122: 1033-1048

59 Hebert AS, Dittenhafer-Reed KE, Yu W, Bailey DJ, Selen ES, Boersma MD, Carson JJ, Tonelli M, Balloon AJ, Higbee AJ, Westphall MS, Pagliarini DJ, Prolla TA, Assadi-Porter F, Roy S, Denu JM, Coon JJ. Calorie restriction and SIRT3 trigger global reprogramming of the mitochondrial protein acetylome. Mol Cell, 2013, 49: 186-199

$60 \mathrm{Lu} \mathrm{C}$, Thompson CB. Metabolic regulation of epigenetics. Cell Metab, 2012, 16: 9-17

61 Wullschleger S, Loewith R, Hall MN. TOR signaling in growth and metabolism. Cell, 2006, 124: 471-484

62 Lin SJ, Kaeberlein M, Andalis AA, Sturtz LA, Defossez PA, Culotta VC, Fink GR, Guarente L. Calorie restriction extends Saccharomyces cerevisiae lifespan by increasing respiration. Nature, 2002, 418: 344-348

63 Lin SJ, Ford E, Haigis M, Liszt G, Guarente L. Calorie restriction extends yeast life span by lowering the level of NADH. Genes Dev, 2004, 18: 12-16

64 Anderson RM, Bitterman KJ, Wood JG, Medvedik O, Sinclair DA. Nicotinamide and PNC1 govern lifespan extension by calorie restriction in Saccharomyces cerevisiae. Nature, 2003, 423: 181-185

65 Lin SJ, Defossez PA, Guarente L. Requirement of NAD and SIR2 for life-span extension by calorie restriction in Saccharomyces cerevisiae. Science, 2000, 289: 2126-2128

66 Rogina B, Helfand SL. Sir2 mediates longevity in the fly through a pathway related to calorie restriction. Proc Natl Acad Sci USA, 2004, 101: 15998-16003

67 Zhou S, Chen HZ, Wan YZ, Zhang QJ, Wei YS, Huang S, Liu JJ, Lu YB, Zhang ZQ, Yang RF, Zhang R, Cai H, Liu DP, Liang CC. Repression of P66Shc expression by SIRT1 contributes to the prevention of hyperglycemia-induced endothelial dysfunction. Circ Res, 2011, 109: 639-648

68 Olmos Y, Sanchez-Gomez FJ, Wild B, Garcia-Quintans N, Cabezudo $\mathrm{S}$, Lamas S, Monsalve M. SirT1 regulation of antioxidant genes is dependent on the formation of a FoxO3a/PGC-1alpha complex. Antioxid Redox Signal, 2013, 19: 1507-1521

69 Kim YH, Hwang JH, Kim KS, Noh JR, Gang GT, Oh WK, Jeong KH, Kwak TH, Choi HS, Lee IK, Lee CH. Enhanced activation of $\mathrm{NAD}(\mathrm{P}) \mathrm{H}$ : quinone oxidoreductase 1 attenuates spontaneous hypertension by improvement of endothelial nitric oxide synthase coupling via tumor suppressor kinase liver kinase B1/adenosine 5 '-monophosphate-activated protein kinase-mediated guanosine 5'-triphosphate cyclohydrolase 1 preservation. J Hypertens, 2014, 32: 306-317

70 Chen Z, Peng IC, Cui X, Li YS, Chien S, Shyy JY. Shear stress, SIRT1, and vascular homeostasis. Proc Natl Acad Sci USA, 2010, 107: 10268-10273

71 Mattagajasingh I, Kim CS, Naqvi A, Yamamori T, Hoffman TA, Jung SB, DeRicco J, Kasuno K, Irani K. SIRT1 promotes endothelium-dependent vascular relaxation by activating endothelial nitric oxide synthase. Proc Natl Acad Sci USA, 2007, 104: 14855-14860

72 Jia YY, Lu J, Huang Y, Liu G, Gao P, Wan YZ, Zhang R, Zhang ZQ, Yang RF, Tang $\mathrm{X}$, Xu J, Wang $\mathrm{X}$, Chen HZ, Liu DP. The involvement of NFAT transcriptional activity suppression in SIRT1-mediated inhibition of COX-2 expression induced by PMA/ionomycin. PLoS ONE, 2014, 9: e97999

73 Wang W, Bai L, Qiao H, Lu Y, Yang L, Zhang J, Lin R, Ren F, Ji M. The protective effect of fenofibrate against TNF-alpha-induced CD40 expression through SIRT1-mediated deacetylation of NF-kappaB in endothelial cells. Inflammation, 2014, 37: 177-185

74 Stein S, Schafer N, Breitenstein A, Besler C, Winnik S, Lohmann C, Heinrich K, Brokopp CE, Handschin C, Landmesser U, Tanner FC, Luscher TF, Matter CM. SIRT1 reduces endothelial activation without affecting vascular function in $\mathrm{ApoE}^{-/-}$mice. Aging (Albany NY), 2010, 2: 353-360

75 Ceolotto G, De Kreutzenberg SV, Cattelan A, Fabricio AS, Squarcina
E, Gion M, Semplicini A, Fadini GP, Avogaro A. Sirtuin 1 stabilization by HuR represses TNF-alpha- and glucose-induced E-selectin release and endothelial cell adhesiveness in vitro: relevance to human metabolic syndrome. Clin Sci (Lond), 2014, 127: 449-461

76 Ota H, Akishita M, Eto M, Iijima K, Kaneki M, Ouchi Y. Sirt1 modulates premature senescence-like phenotype in human endothelial cells. J Mol Cell Cardiol, 2007, 43: 571-579

77 Han X, Ling S, Gan W, Sun L, Duan J, Xu JW. 2,3,5,4'tetrahydroxystilbene-2-O-beta-d-glucoside ameliorates vascular senescence and improves blood flow involving a mechanism of p53 deacetylation. Atherosclerosis, 2012, 225: 76-82

78 Lin YJ, Zhen YZ, Wei J, Liu B, Yu ZY, Hu G. Effects of Rhein lysinate on $\mathrm{H}_{2} \mathrm{O}_{2}$-induced cellular senescence of human umbilical vascular endothelial cells. Acta Pharmacol Sin, 2011, 32: 1246-1252

79 Arunachalam G, Samuel SM, Marei I, Ding H, Triggle CR. Metformin modulates hyperglycaemia-induced endothelial senescence and apoptosis through SIRT1. Br J Pharmacol, 2014, 171: 523-535

80 Orimo M, Minamino T, Miyauchi H, Tateno K, Okada S, Moriya J, Komuro I. Protective role of SIRT1 in diabetic vascular dysfunction. Arterioscler Thromb Vasc Biol, 2009, 29: 889-894

81 Zu Y, Liu L, Lee MY, Xu C, Liang Y, Man RY, Vanhoutte PM, Wang Y. SIRT1 promotes proliferation and prevents senescence through targeting LKB1 in primary porcine aortic endothelial cells. Circ Res, 2010, 106: 1384-1393

82 Wan YZ, Gao P, Zhou S, Zhang ZQ, Hao DL, Lian LS, Li YJ, Chen HZ, Liu DP. SIRT1-mediated epigenetic downregulation of plasminogen activator inhibitor-1 prevents vascular endothelial replicative senescence. Aging Cell, 2014, In press, doi: 10.1111/acel.12247

83 Minamino T, Miyauchi H, Yoshida T, Ishida Y, Yoshida H, Komuro I. Endothelial cell senescence in human atherosclerosis: role of telomere in endothelial dysfunction. Circulation, 2002, 105: 1541-1544

84 Guarani V, Deflorian G, Franco CA, Kruger M, Phng LK, Bentley K, Toussaint L, Dequiedt F, Mostoslavsky R, Schmidt MH, Zimmermann B, Brandes RP, Mione M, Westphal CH, Braun T, Zeiher AM, Gerhardt H, Dimmeler S, Potente M. Acetylationdependent regulation of endothelial Notch signalling by the SIRT1 deacetylase. Nature, 2011, 473: 234-238

85 Xiong S, Salazar G, Patrushev N, Alexander RW. FoxO1 mediates an autofeedback loop regulating SIRT1 expression. J Biol Chem, 2011, 286: 5289-5299

86 Gorenne I, Kumar S, Gray K, Figg N, Yu H, Mercer J, Bennett M. Vascular smooth muscle cell sirtuin 1 protects against DNA damage and inhibits atherosclerosis. Circulation, 2013, 127: 386-396

87 van der Veer E, Ho C, O'Neil C, Barbosa N, Scott R, Cregan SP, Pickering JG. Extension of human cell lifespan by nicotinamide phosphoribosyltransferase. J Biol Chem, 2007, 282: 10841-10845

88 Takemura A, Iijima K, Ota H, Son BK, Ito Y, Ogawa S, Eto M, Akishita M, Ouchi Y. Sirtuin 1 retards hyperphosphatemia-induced calcification of vascular smooth muscle cells. Arterioscler Thromb Vasc Biol, 2011, 31: 2054-2062

89 Gao P, Xu TT, Lu J, Li L, Xu J, Hao DL, Chen HZ, Liu DP. Overexpression of SIRT1 in vascular smooth muscle cells attenuates angiotensin II-induced vascular remodeling and hypertension in mice. J Mol Med (Berl), 2014, 92: 347-357

90 Li L, Zhang HN, Chen HZ, Gao P, Zhu LH, Li HL, Lv X, Zhang QJ, Zhang R, Wang Z, She ZG, Wei YS, Du GH, Liu DP, Liang CC. SIRT1 acts as a modulator of neointima formation following vascular injury in mice. Circ Res, 2011, 108: 1180-1189

91 Xia J, Wu X, Yang Y, Zhao Y, Fang M, Xie W, Wang H, Xu Y. SIRT1 deacetylates RFX5 and antagonizes repression of collagen type I (COL1A2) transcription in smooth muscle cells. Biochem Biophys Res Commun, 2012, 428: 264-270

92 Zhang R, Chen HZ, Liu JJ, Jia YY, Zhang ZQ, Yang RF, Zhang Y, $\mathrm{Xu}$ J, Wei YS, Liu DP, Liang CC. SIRT1 suppresses activator protein-1 transcriptional activity and cyclooxygenase-2 expression in 
macrophages. J Biol Chem, 2010, 285: 7097-7110

93 Xue B, Yang Z, Wang X, Shi H. Omega-3 polyunsaturated fatty acids antagonize macrophage inflammation via activation of AMPK/SIRT1 pathway. PLoS ONE, 2012, 7: e45990

94 Stein S, Lohmann C, Schafer N, Hofmann J, Rohrer L, Besler C, Rothgiesser KM, Becher B, Hottiger MO, Boren J, McBurney MW, Landmesser U, Luscher TF, Matter CM. SIRT1 decreases Lox-1-mediated foam cell formation in atherogenesis. Eur Heart J, 2010, 31: 2301-2309

95 Cohen HY, Miller C, Bitterman KJ, Wall NR, Hekking B, Kessler B, Howitz KT, Gorospe M, de Cabo R, Sinclair DA. Calorie restriction promotes mammalian cell survival by inducing the SIRT1 deacetylase. Science, 2004, 305: 390-392

96 Qin W, Yang T, Ho L, Zhao Z, Wang J, Chen L, Zhao W, Thiyagarajan M, MacGrogan D, Rodgers JT, Puigserver P, Sadoshima J, Deng H, Pedrini S, Gandy S, Sauve AA, Pasinetti GM. Neuronal SIRT1 activation as a novel mechanism underlying the prevention of Alzheimer disease amyloid neuropathology by calorie restriction. J Biol Chem, 2006, 281: 21745-21754

97 Nisoli E, Tonello C, Cardile A, Cozzi V, Bracale R, Tedesco L, Falcone S, Valerio A, Cantoni O, Clementi E, Moncada S, Carruba MO. Calorie restriction promotes mitochondrial biogenesis by inducing the expression of eNOS. Science, 2005, 310: 314-317

98 Firestein R, Blander G, Michan S, Oberdoerffer P, Ogino S, Campbell J, Bhimavarapu A, Luikenhuis S, de Cabo R, Fuchs C, Hahn WC, Guarente LP, Sinclair DA. The SIRT1 deacetylase suppresses intestinal tumorigenesis and colon cancer growth. PLoS ONE, 2008, 3: e2020

99 Zhang QJ, Wang Z, Chen HZ, Zhou S, Zheng W, Liu G, Wei YS, Cai H, Liu DP, Liang CC. Endothelium-specific overexpression of class III deacetylase SIRT1 decreases atherosclerosis in apolipoprotein E-deficient mice. Cardiovasc Res, 2008, 80: 191-199

100 Civitarese AE, Carling S, Heilbronn LK, Hulver MH, Ukropcova B, Deutsch WA, Smith SR, Ravussin E. Calorie restriction increases muscle mitochondrial biogenesis in healthy humans. PLoS Med, 2007, 4: e76

101 Chalkiadaki A, Guarente L. High-fat diet triggers inflammationinduced cleavage of SIRT1 in adipose tissue to promote metabolic dysfunction. Cell Metab, 2012, 16: 180-188

102 Costa Cdos S, Hammes TO, Rohden F, Margis R, Bortolotto JW, Padoin AV, Mottin CC, Guaragna RM. SIRT1 transcription is decreased in visceral adipose tissue of morbidly obese patients with severe hepatic steatosis. Obes Surg, 2010, 20: 633-639

103 Pedersen SB, Olholm J, Paulsen SK, Bennetzen MF, Richelsen B. Low Sirt1 expression, which is upregulated by fasting, in human adipose tissue from obese women. Int J Obes (Lond), 2008, 32: 1250-1255

104 Chen D, Steele AD, Lindquist S, Guarente L. Increase in activity during calorie restriction requires Sirt1. Science, 2005, 310: 1641

105 Boily G, Seifert EL, Bevilacqua L, He XH, Sabourin G, Estey C, Moffat C, Crawford S, Saliba S, Jardine K, Xuan J, Evans M, Harper ME, McBurney MW. SirT1 regulates energy metabolism and response to caloric restriction in mice. PLoS ONE, 2008, 3: e1759

106 Bordone L, Cohen D, Robinson A, Motta MC, van Veen E, Czopik A, Steele AD, Crowe H, Marmor S, Luo J, Gu W, Guarente L. SIRT1 transgenic mice show phenotypes resembling calorie restriction. Aging Cell, 2007, 6: 759-767

107 Price NL, Gomes AP, Ling AJ, Duarte FV, Martin-Montalvo A, North BJ, Agarwal B, Ye L, Ramadori G, Teodoro JS, Hubbard BP, Varela AT, Davis JG, Varamini B, Hafner A, Moaddel R, Rolo AP, Coppari R, Palmeira CM, de Cabo R, Baur JA, Sinclair DA. SIRT1 is required for AMPK activation and the beneficial effects of resveratrol on mitochondrial function. Cell Metab, 2012, 15: 675-690

108 Purushotham A, Schug TT, Xu Q, Surapureddi S, Guo X, Li X. Hepatocyte-specific deletion of SIRT1 alters fatty acid metabolism and results in hepatic steatosis and inflammation. Cell Metab, 2009, 9: 327-338

109 Sun C, Zhang F, Ge X, Yan T, Chen X, Shi X, Zhai Q. SIRT1 improves insulin sensitivity under insulin-resistant conditions by repressing PTP1B. Cell Metab, 2007, 6: 307-319

110 Picard F, Kurtev M, Chung N, Topark-Ngarm A, Senawong T, Machado De Oliveira R, Leid M, McBurney MW, Guarente L. Sirt1 promotes fat mobilization in white adipocytes by repressing PPAR-gamma. Nature, 2004, 429: 771-776

111 Hirschey MD, Shimazu T, Capra JA, Pollard KS, Verdin E. SIRT1 and SIRT3 deacetylate homologous substrates: AceCS1,2 and HMGCS1,2. Aging (Albany NY), 2011, 3: 635-642

112 Lombard DB, Alt FW, Cheng HL, Bunkenborg J, Streeper RS, Mostoslavsky R, Kim J, Yancopoulos G, Valenzuela D, Murphy A, Yang Y, Chen Y, Hirschey MD, Bronson RT, Haigis M, Guarente LP, Farese RV Jr., Weissman S, Verdin E, Schwer B. Mammalian Sir2 homolog SIRT3 regulates global mitochondrial lysine acetylation. Mol Cell Biol, 2007, 27: 8807-8814

113 Rardin MJ, Newman JC, Held JM, Cusack MP, Sorensen DJ, Li B, Schilling B, Mooney SD, Kahn CR, Verdin E, Gibson BW. Label-free quantitative proteomics of the lysine acetylome in mitochondria identifies substrates of SIRT3 in metabolic pathways. Proc Natl Acad Sci USA, 2013, 110: 6601-6606

114 Waypa GB, Osborne SW, Marks JD, Berkelhamer SK, Kondapalli J, Schumacker PT. Sirtuin 3 deficiency does not augment hypoxia-induced pulmonary hypertension. Am J Respir Cell Mol Biol, 2013, 49: 885-891

115 Winnik S, Gaul DS, Preitner F, Lohmann C, Weber J, Miranda MX, Liu Y, van Tits LJ, Mateos JM, Brokopp CE, Auwerx J, Thorens B, Luscher TF, Matter CM. Deletion of Sirt3 does not affect atherosclerosis but accelerates weight gain and impairs rapid metabolic adaptation in LDL receptor knockout mice: implications for cardiovascular risk factor development. Basic Res Cardiol, 2014, 109: 399

116 Palacios OM, Carmona JJ, Michan S, Chen KY, Manabe Y, Ward JL, 3rd, Goodyear LJ, Tong Q. Diet and exercise signals regulate SIRT3 and activate AMPK and PGC-1alpha in skeletal muscle. Aging (Albany NY), 2009, 1: 771-783

117 Shi T, Wang F, Stieren E, Tong Q. SIRT3, a mitochondrial sirtuin deacetylase, regulates mitochondrial function and thermogenesis in brown adipocytes. J Biol Chem, 2005, 280: 13560-13567

118 Hallows WC, Yu W, Smith BC, Devries MK, Ellinger JJ, Someya S, Shortreed MR, Prolla T, Markley JL, Smith LM, Zhao S, Guan KL, Denu JM. Sirt3 promotes the urea cycle and fatty acid oxidation during dietary restriction. Mol Cell, 2011, 41: 139-149

119 Shimazu T, Hirschey MD, Hua L, Dittenhafer-Reed KE, Schwer B, Lombard DB, Li Y, Bunkenborg J, Alt FW, Denu JM, Jacobson MP, Verdin E. SIRT3 deacetylates mitochondrial 3-hydroxy-3methylglutaryl CoA synthase 2 and regulates ketone body production. Cell Metab, 2010, 12: 654-661

120 Hirschey MD, Shimazu T, Goetzman E, Jing E, Schwer B, Lombard DB, Grueter CA, Harris C, Biddinger S, Ilkayeva OR, Stevens RD, Li Y, Saha AK, Ruderman NB, Bain JR, Newgard CB, Farese RV Jr., Alt FW, Kahn CR, Verdin E. SIRT3 regulates mitochondrial fatty-acid oxidation by reversible enzyme deacetylation. Nature, 2010, 464: $121-125$

121 Qiu X, Brown K, Hirschey MD, Verdin E, Chen D. Calorie restriction reduces oxidative stress by SIRT3-mediated SOD2 activation. Cell Metab, 2010, 12: 662-667

122 Someya S, Yu W, Hallows WC, Xu J, Vann JM, Leeuwenburgh C, Tanokura M, Denu JM, Prolla TA. Sirt3 mediates reduction of oxidative damage and prevention of age-related hearing loss under caloric restriction. Cell, 2010, 143: 802-812

123 Houtkooper RH, Pirinen E, Auwerx J. Sirtuins as regulators of metabolism and healthspan. Nat Rev Mol Cell Biol, 2012, 13: 225-238

124 Chalkiadaki A, Guarente L. Sirtuins mediate mammalian metabolic responses to nutrient availability. Nat Rev Endocrinol, 2012, 8: 287-296

125 Guarente L. Calorie restriction and sirtuins revisited. Genes Dev, 2013, 27: 2072-2085

126 Hardie DG, Ross FA, Hawley SA. AMPK: a nutrient and energy sensor that maintains energy homeostasis. Nat Rev Mol Cell Biol, 
2012, 13: 251-262

127 Hardie DG. AMP-activated protein kinase: an energy sensor that regulates all aspects of cell function. Genes Dev, 2011, 25: 1895-1908

128 Shirwany NA, Zou MH. AMPK in cardiovascular health and disease. Acta Pharmacol Sin, 2010, 31: 1075-1084

129 Fisslthaler B, Fleming I. Activation and signaling by the AMP-activated protein kinase in endothelial cells. Circ Res, 2009, 105: 114-127

130 Morrow VA, Foufelle F, Connell JM, Petrie JR, Gould GW, Salt IP. Direct activation of AMP-activated protein kinase stimulates nitric-oxide synthesis in human aortic endothelial cells. J Biol Chem, 2003, 278: 31629-31639

131 Chen ZP, Mitchelhill KI, Michell BJ, Stapleton D, Rodriguez-Crespo I, Witters LA, Power DA, Ortiz de Montellano PR, Kemp BE. AMP-activated protein kinase phosphorylation of endothelial NO synthase. FEBS Lett, 1999, 443: 285-289

132 Chen Z, Peng IC, Sun W, Su MI, Hsu PH, Fu Y, Zhu Y, DeFea K, Pan S, Tsai MD, Shyy JY. AMP-activated protein kinase functionally phosphorylates endothelial nitric oxide synthase Ser633. Circ Res, 2009, 104: 496-505

133 Colombo SL, Moncada S. AMPKalphal regulates the antioxidant status of vascular endothelial cells. Biochem J, 2009, 421: 163-169

134 Schulz E, Dopheide J, Schuhmacher S, Thomas SR, Chen K, Daiber A, Wenzel P, Munzel T, Keaney JF, Jr. Suppression of the JNK pathway by induction of a metabolic stress response prevents vascular injury and dysfunction. Circulation, 2008, 118: 1347-1357

135 Mount PF, Lane N, Venkatesan S, Steinberg GR, Fraser SA, Kemp BE, Power DA. Bradykinin stimulates endothelial cell fatty acid oxidation by CaMKK-dependent activation of AMPK. Atherosclerosis, 2008, 200: 28-36

136 Ido Y, Carling D, Ruderman N. Hyperglycemia-induced apoptosis in human umbilical vein endothelial cells: inhibition by the AMPactivated protein kinase activation. Diabetes, 2002, 51: 159-167

137 Lee WJ, Lee IK, Kim HS, Kim YM, Koh EH, Won JC, Han SM, Kim MS, Jo I, Oh GT, Park IS, Youn JH, Park SW, Lee KU, Park JY. Alpha-lipoic acid prevents endothelial dysfunction in obese rats via activation of AMP-activated protein kinase. Arterioscler Thromb Vasc Biol, 2005, 25: 2488-2494

138 Goirand F, Solar M, Athea Y, Viollet B, Mateo P, Fortin D, Leclerc J, Hoerter J, Ventura-Clapier R, Garnier A. Activation of AMP kinase alpha1 subunit induces aortic vasorelaxation in mice. J Physiol, 2007, 581: 1163-1171

139 Song P, Wang S, He C, Liang B, Viollet B, Zou MH. AMPKalpha2 deletion exacerbates neointima formation by upregulating Skp2 in vascular smooth muscle cells. Circ Res, 2011, 109: 1230-1239

140 Wang S, Zhang C, Zhang M, Liang B, Zhu H, Lee J, Viollet B, Xia L, Zhang Y, Zou MH. Activation of AMP-activated protein kinase alpha2 by nicotine instigates formation of abdominal aortic aneurysms in mice in vivo. Nat Med, 2012, 18: 902-910

141 Sag D, Carling D, Stout RD, Suttles J. Adenosine 5'monophosphate-activated protein kinase promotes macrophage polarization to an anti-inflammatory functional phenotype. J Immunol, 2008, 181: 8633-8641

142 Jeong HW, Hsu KC, Lee JW, Ham M, Huh JY, Shin HJ, Kim WS, Kim JB. Berberine suppresses proinflammatory responses through AMPK activation in macrophages. Am J Physiol Endocrinol Metab, 2009, 296: E955-964

143 Yang Z, Kahn BB, Shi H, Xue BZ. Macrophage alpha1 AMPactivated protein kinase (alpha1AMPK) antagonizes fatty acid-induced inflammation through SIRT1. J Biol Chem, 2010, 285: 19051-19059

144 Mounier R, Theret M, Arnold L, Cuvellier S, Bultot L, Goransson O, Sanz N, Ferry A, Sakamoto K, Foretz M, Viollet B, Chazaud B. AMPKalpha1 regulates macrophage skewing at the time of resolution of inflammation during skeletal muscle regeneration. Cell Metab, 2013, 18: 251-264

145 Galic S, Fullerton MD, Schertzer JD, Sikkema S, Marcinko K, Walkley CR, Izon D, Honeyman J, Chen ZP, van Denderen BJ,
Kemp BE, Steinberg GR. Hematopoietic AMPK beta1 reduces mouse adipose tissue macrophage inflammation and insulin resistance in obesity. J Clin Invest, 2011, 121: 4903-4915

146 Greer EL, Dowlatshahi D, Banko MR, Villen J, Hoang K, Blanchard D, Gygi SP, Brunet A. An AMPK-FOXO pathway mediates longevity induced by a novel method of dietary restriction in $C$. elegans. Curr Biol, 2007, 17: 1646-1656

147 Greer EL, Brunet A. Different dietary restriction regimens extend lifespan by both independent and overlapping genetic pathways in $\mathrm{C}$. elegans. Aging Cell, 2009, 8: 113-127

148 Schulz TJ, Zarse K, Voigt A, Urban N, Birringer M, Ristow M. Glucose restriction extends Caenorhabditis elegans life span by inducing mitochondrial respiration and increasing oxidative stress. Cell Metab, 2007, 6: 280-293

149 Kondo M, Shibata R, Miura R, Shimano M, Kondo K, Li P, Ohashi T, Kihara S, Maeda N, Walsh K, Ouchi N, Murohara T. Caloric restriction stimulates revascularization in response to ischemia via adiponectin-mediated activation of endothelial nitric-oxide synthase. J Biol Chem, 2009, 284: 1718-1724

150 Shinmura K, Tamaki K, Saito K, Nakano Y, Tobe T, Bolli R. Cardioprotective effects of short-term caloric restriction are mediated by adiponectin via activation of AMP-activated protein kinase. Circulation, 2007, 116: 2809-2817

151 Edwards AG, Donato AJ, Lesniewski LA, Gioscia RA, Seals DR, Moore RL. Life-long caloric restriction elicits pronounced protection of the aged myocardium: a role for AMPK. Mech Ageing Dev, 2010, 131: 739-742

152 Fulco M, Cen Y, Zhao P, Hoffman EP, McBurney MW, Sauve AA, Sartorelli V. Glucose restriction inhibits skeletal myoblast differentiation by activating SIRT1 through AMPK-mediated regulation of Nampt. Dev Cell, 2008, 14: 661-673

153 Feige JN, Lagouge M, Canto C, Strehle A, Houten SM, Milne JC, Lambert PD, Mataki C, Elliott PJ, Auwerx J. Specific SIRT1 activation mimics low energy levels and protects against diet-induced metabolic disorders by enhancing fat oxidation. Cell Metab, 2008, 8: 347-358

154 Hou X, Xu S, Maitland-Toolan KA, Sato K, Jiang B, Ido Y, Lan F, Walsh K, Wierzbicki M, Verbeuren TJ, Cohen RA, Zang M. SIRT1 regulates hepatocyte lipid metabolism through activating AMPactivated protein kinase. J Biol Chem, 2008, 283: 20015-20026

155 Lan F, Cacicedo JM, Ruderman N, Ido Y. SIRT1 modulation of the acetylation status, cytosolic localization, and activity of LKB1. Possible role in AMP-activated protein kinase activation. J Biol Chem, 2008, 283: 27628-27635

156 Canto C, Gerhart-Hines Z, Feige JN, Lagouge M, Noriega L, Milne JC, Elliott PJ, Puigserver P, Auwerx J. AMPK regulates energy expenditure by modulating $\mathrm{NAD}^{+}$metabolism and SIRT1 activity. Nature, 2009, 458: 1056-1060

157 Shulga N, Pastorino JG. Ethanol sensitizes mitochondria to the permeability transition by inhibiting deacetylation of cyclophilin-D mediated by sirtuin-3. J Cell Sci, 2010, 123: 4117-4127

158 Pillai VB, Sundaresan NR, Kim G, Gupta M, Rajamohan SB, Pillai JB, Samant S, Ravindra PV, Isbatan A, Gupta MP. Exogenous NAD blocks cardiac hypertrophic response via activation of the SIRT3-LKB1-AMP-activated kinase pathway. J Biol Chem, 2010, 285: 3133-3144

159 Zhang Y, Lee TS, Kolb EM, Sun K, Lu X, Sladek FM, Kassab GS, Garland T, Jr., Shyy JY. AMP-activated protein kinase is involved in endothelial NO synthase activation in response to shear stress. Arterioscler Thromb Vasc Biol, 2006, 26: 1281-1287

160 Zoncu R, Efeyan A, Sabatini DM. mTOR: from growth signal integration to cancer, diabetes and ageing. Nat Rev Mol Cell Biol, 2011, 12: 21-35

161 Chong ZZ, Shang YC, Maiese K. Cardiovascular disease and mTOR signaling. Trends Cardiovasc Med, 2011, 21: 151-155

162 Moses JW, Leon MB, Popma JJ, Fitzgerald PJ, Holmes DR, O'Shaughnessy C, Caputo RP, Kereiakes DJ, Williams DO, Teirstein PS, Jaeger JL, Kuntz RE. Sirolimus-eluting stents versus standard stents in patients with stenosis in a native coronary artery. $\mathrm{N}$ Engl $\mathrm{J}$ 
Med, 2003, 349: 1315-1323

163 Houssaini A, Abid S, Mouraret N, Wan F, Rideau D, Saker M, Marcos E, Tissot CM, Dubois-Rande JL, Amsellem V, Adnot S. Rapamycin reverses pulmonary artery smooth muscle cell proliferation in pulmonary hypertension. Am J Respir Cell Mol Biol, 2013, 48: 568-577

164 Rajapakse AG, Yepuri G, Carvas JM, Stein S, Matter CM, Scerri I, Ruffieux J, Montani JP, Ming XF, Yang Z. Hyperactive S6K1 mediates oxidative stress and endothelial dysfunction in aging: inhibition by resveratrol. PLoS ONE, 2011, 6: e19237

165 Beutner F, Brendel D, Teupser D, Sass K, Baber R, Mueller M, Ceglarek U, Thiery J. Effect of everolimus on pre-existing atherosclerosis in LDL-receptor deficient mice. Atherosclerosis, 2012, 222: 337-343

166 Mueller MA, Beutner F, Teupser D, Ceglarek U, Thiery J. Prevention of atherosclerosis by the mTOR inhibitor everolimus in $\mathrm{LDLR}^{-/}$ mice despite severe hypercholesterolemia. Atherosclerosis, 2008, 198: $39-48$

167 Elloso MM, Azrolan N, Sehgal SN, Hsu PL, Phiel KL, Kopec CA, Basso MD, Adelman SJ. Protective effect of the immunosuppressant sirolimus against aortic atherosclerosis in apo E-deficient mice. Am J Transplant, 2003, 3: 562-569

168 Castro C, Campistol JM, Sancho D, Sanchez-Madrid F, Casals E, Andres V. Rapamycin attenuates atherosclerosis induced by dietary cholesterol in apolipoprotein-deficient mice through a p27 Kip1-independent pathway. Atherosclerosis, 2004, 172: 31-38

169 Pakala R, Stabile E, Jang GJ, Clavijo L, Waksman R. Rapamycin attenuates atherosclerotic plaque progression in apolipoprotein $\mathrm{E}$ knockout mice: inhibitory effect on monocyte chemotaxis. J Cardiovasc Pharmacol, 2005, 46: 481-486

170 Johnson SC, Rabinovitch PS, Kaeberlein M. mTOR is a key modulator of ageing and age-related disease. Nature, 2013, 493: 338-345

171 Blagosklonny MV. Calorie restriction: decelerating mTOR-driven aging from cells to organisms (including humans). Cell Cycle, 2010, 9: 683-688

172 Hansen M, Taubert S, Crawford D, Libina N, Lee SJ, Kenyon C. Lifespan extension by conditions that inhibit translation in Caenorhabditis elegans. Aging Cell, 2007, 6: 95-110

173 Bjedov I, Toivonen JM, Kerr F, Slack C, Jacobson J, Foley A, Partridge L. Mechanisms of life span extension by rapamycin in the fruit fly Drosophila melanogaster. Cell Metab, 2010, 11: 35-46

174 Kapahi P, Zid BM, Harper T, Koslover D, Sapin V, Benzer S. Regulation of lifespan in Drosophila by modulation of genes in the TOR signaling pathway. Curr Biol, 2004, 14: 885-890

175 Kaeberlein M, Powers RW, 3rd, Steffen KK, Westman EA, Hu D, Dang N, Kerr EO, Kirkland KT, Fields S, Kennedy BK. Regulation of yeast replicative life span by TOR and Sch9 in response to nutrients. Science, 2005, 310: 1193-1196

176 Hansen M, Chandra A, Mitic LL, Onken B, Driscoll M, Kenyon C. A role for autophagy in the extension of lifespan by dietary restriction in C. elegans. PLoS Genet, 2008, 4: e24

177 Harrison DE, Strong R, Sharp ZD, Nelson JF, Astle CM, Flurkey K, Nadon NL, Wilkinson JE, Frenkel K, Carter CS, Pahor M, Javors MA, Fernandez E, Miller RA. Rapamycin fed late in life extends lifespan in genetically heterogeneous mice. Nature, 2009, 460: 392-395

178 Lamming DW, Ye L, Kataisto P, Goncalves MD, Saitoh M, Stevens DM, Davis JG, Salmon AB, Richardson A, Ahima RS, Guertin DA, Sabatini DM, Baur JA. Rapamycin-induced insulin resistance is mediated by mTORC2 loss and uncoupled from longevity. Science, 2012, 335: 1638-1643

179 Anisimov VN, Zabezhinski MA, Popovich IG, Piskunova TS,
Semenchenko AV, Tyndyk ML, Yurova MN, Rosenfeld SV, Blagosklonny MV. Rapamycin increases lifespan and inhibits spontaneous tumorigenesis in inbred female mice. Cell Cycle, 2011, 10: $4230-4236$

180 Selman C, Tullet JM, Wieser D, Irvine E, Lingard SJ, Choudhury AI, Claret M, Al-Qassab H, Carmignac D, Ramadani F, Woods A, Robinson IC, Schuster E, Batterham RL, Kozma SC, Thomas G, Carling D, Okkenhaug K, Thornton JM, Partridge L, Gems D, Withers DJ. Ribosomal protein S6 kinase 1 signaling regulates mammalian life span. Science, 2009, 326: 140-144

181 Aguilar V, Alliouachene S, Sotiropoulos A, Sobering A, Athea Y, Djouadi F, Miraux S, Thiaudiere E, Foretz M, Viollet B, Diolez P, Bastin J, Benit P, Rustin P, Carling D, Sandri M, Ventura-Clapier R, Pende M. S6 kinase deletion suppresses muscle growth adaptations to nutrient availability by activating AMP kinase. Cell Metab, 2007, 5: 476-487

182 Shaw RJ. LKB1 and AMP-activated protein kinase control of mTOR signalling and growth. Acta Physiol (Oxf), 2009, 196: 65-80

183 Ghosh HS, McBurney M, Robbins PD. SIRT1 negatively regulates the mammalian target of rapamycin. PLoS ONE, 2010, 5: e9199

184 Guo W, Qian L, Zhang J, Zhang W, Morrison A, Hayes P, Wilson S, Chen T, Zhao J. Sirtl overexpression in neurons promotes neurite outgrowth and cell survival through inhibition of the mTOR signaling. J Neurosci Res, 2011, 89: 1723-1736

185 Wang CY, Kim HH, Hiroi Y, Sawada N, Salomone S, Benjamin LE, Walsh K, Moskowitz MA, Liao JK. Obesity increases vascular senescence and susceptibility to ischemic injury through chronic activation of Akt and mTOR. Sci Signal, 2009, 2: ra11

186 Canto C, Auwerx J. Caloric restriction, SIRT1 and longevity. Trends Endocrinol Metab, 2009, 20: 325-331

187 Kawashima S, Yokoyama M. Dysfunction of endothelial nitric oxide synthase and atherosclerosis. Arterioscler Thromb Vasc Biol, 2004, 24: $998-1005$

188 Forstermann U, Munzel T. Endothelial nitric oxide synthase in vascular disease: from marvel to menace. Circulation, 2006, 113: 1708-1714

189 Cook S, Hugli O, Egli M, Vollenweider P, Burcelin R, Nicod P, Thorens B, Scherrer U. Clustering of cardiovascular risk factors mimicking the human metabolic syndrome $\mathrm{X}$ in eNOS null mice. Swiss Med Wkly, 2003, 133: 360-363

190 Sansbury BE, Cummins TD, Tang Y, Hellmann J, Holden CR, Harbeson MA, Chen Y, Patel RP, Spite M, Bhatnagar A, Hill BG. Overexpression of endothelial nitric oxide synthase prevents diet-induced obesity and regulates adipocyte phenotype. Circ Res, 2012, 111: 1176-1189

191 Ota H, Eto M, Kano MR, Ogawa S, Iijima K, Akishita M, Ouchi Y. Cilostazol inhibits oxidative stress-induced premature senescence via upregulation of Sirt1 in human endothelial cells. Arterioscler Thromb Vasc Biol, 2008, 28: 1634-1639

192 Zhang J, Xie Z, Dong Y, Wang S, Liu C, Zou MH. Identification of nitric oxide as an endogenous activator of the AMP-activated protein kinase in vascular endothelial cells. J Biol Chem, 2008, 283: 27452-27461

193 Shinmura K, Tamaki K, Bolli R. Impact of 6-mo caloric restriction on myocardial ischemic tolerance: possible involvement of nitric oxide-dependent increase in nuclear Sirt1. Am J Physiol Heart Circ Physiol, 2008, 295: H2348-2355

194 Zou MH, Kirkpatrick SS, Davis BJ, Nelson JS, Wiles WGt, Schlattner U, Neumann D, Brownlee M, Freeman MB, Goldman MH. Activation of the AMP-activated protein kinase by the anti-diabetic drug metformin in vivo. Role of mitochondrial reactive nitrogen species. J Biol Chem, 2004, 279: 43940-43951

Open Access This article is distributed under the terms of the Creative Commons Attribution License which permits any use, distribution, and reproduction in any medium, provided the original author(s) and source are credited. 